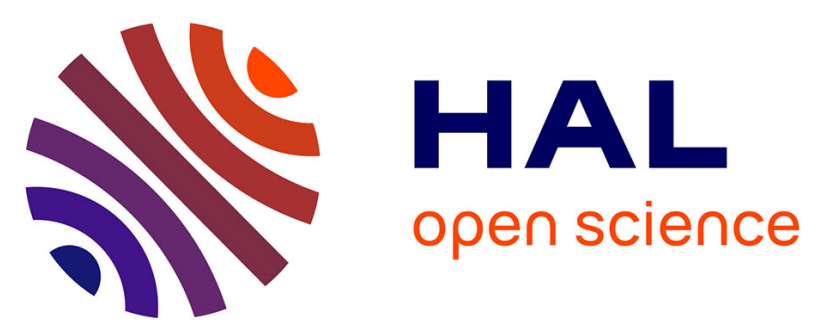

\title{
Fuel Cell, Battery and Supercapacitor Hybrid System for Electric Vehicle: Modeling and Control via Energetic Macroscopic Representation
}

Lucia Gauchia, Alain Bouscayrol, Javier Sanz, Rochdi Trigui, Philippe Barrade

\section{To cite this version:}

Lucia Gauchia, Alain Bouscayrol, Javier Sanz, Rochdi Trigui, Philippe Barrade. Fuel Cell, Battery and Supercapacitor Hybrid System for Electric Vehicle: Modeling and Control via Energetic Macroscopic Representation. Vehicle Power and Propulsion Conference, Sep 2011, CHICAGO, United States. 6 p., 10.1109/VPPC.2011.6043246 . hal-01218789

\section{HAL Id: hal-01218789 \\ https://hal.science/hal-01218789}

Submitted on 21 Oct 2015

HAL is a multi-disciplinary open access archive for the deposit and dissemination of scientific research documents, whether they are published or not. The documents may come from teaching and research institutions in France or abroad, or from public or private research centers.
L'archive ouverte pluridisciplinaire HAL, est destinée au dépôt et à la diffusion de documents scientifiques de niveau recherche, publiés ou non, émanant des établissements d'enseignement et de recherche français ou étrangers, des laboratoires publics ou privés. 


\title{
Fuel Cell, Battery and Supercapacitor Hybrid System for Electric Vehicle: Modeling and Control via Energetic Macroscopic Representation
}

\author{
L. Gauchia ${ }^{1,5}$, A. Bouscayrol ${ }^{2,5}$, J. Sanz ${ }^{1}$, R. Trigui ${ }^{3,5}$, P. Barrade ${ }^{4}$ \\ ${ }^{1}$ Carlos III University. C/Butarque 15, 28911 Leganés, Madrid (Spain) \\ lgauchia@ing.uc3m.es, jsanz@ing.uc3m.es \\ ${ }^{2}$ L2EP, Université de Lille1. 59655 Villeneuve d'Ascq cedex (France) \\ Alain.Bouscayrol@univ-lille1.fr \\ ${ }^{3}$ LTE, Institute Française des Sciences et Technologies des Transport, de l'Aménagement et des Réseaux. 25 Av. François \\ Mitterand. F-69675 BRON cedex, France \\ Rochdi.trigui@inrets.fr \\ ${ }^{4}$ LEI, École Polytechnique de Lausanne. 1015 Lausanne (Switzerland) \\ Philippe.barrade@epfl.ch \\ ${ }^{5}$ MEGEVH : Modélisation Energétique et Gestion d'Énergie des Véhicules Hybrides. (French network for HEV research)
}

\begin{abstract}
Nowadays, no electrochemical energy system presents a competitive operation if compared with internal combustion engine, which is the reason for combining electrochemical energy systems to obtain a hybrid energy storage system. This paper presents a fuel cell-battery-ultracapacitor system for vehicle application. The objective of this paper is to present the Energetic Macroscopic Representation (EMR) of the multisource power system.
\end{abstract}

\section{INTRODUCTION}

Current fossil fuel vehicles present a high energy and power density operation which still cannot be matched by any electrochemical energy system on its own. However, reducing oil reserves and environmental concerns due to pollutant emissions have activated the research for electrochemical energy systems. One of the current research lines is the hybridization of energy storage systems (ESS), in order to obtain competitive vehicle operation.

Electric vehicles (EVs) allow a wide range of topologies, depending on the energy systems involved [1]. The high energy density needed to compete with ICE can be obtained from high energy density batteries or fuel cells. Fuel cells, especially PEM (Proton Exchange Membrane) fuel cells present a particularly high energy density if compared to the rest of electrochemical energy systems. This is due to the fact that the fuel is stored in a separate tank, just the opposite to batteries. However, they present a poor ramp up capability, due to mass transport phenomena [2] related to the protons concentration on the cathode side.

Therefore, PEM fuel cells can be complemented with high power energy storage systems which are capable of both generating and absorbing high power peaks. The ESS can be supercapacitors or batteries or non electrochemical systems, such as flywheels.
These electrochemical systems admit a varied combination between the fuel cell, battery and supercapacitor. Depending on the topology, the power management will change. For example, for the FC-B case, the battery will be under severe power bursts [3] which could shorten the battery life time. The FC-SC combination could improve this, as supercapacitors present higher power, ramp capability and life cycle than batteries [4], but supercapacitors present much lower energy density than batteries [5]. Moreover, it could present problems during vehicle start-up [6]. The B-SC combination could solve this last aspect, but it will reduce the total energy density due to the fact that batteries still have a lower energy density than fuel cells $[7,8]$. Therefore, the FCB-SC combination keeps the high energy density due to the fuel cell, the high power density and ramp capability due to supercapacitors and batteries, as studied by Thounthong [9] and Schaltz [10].

The objective of this work is to present a fuel cell-batterysupercapacitor electric vehicle, from modeling to control. This is done using Energetic Macroscopic Representation, which allows representation of multiphysical system and its strategy and control.

\section{EMR OF THE ELECTRIC VEHICLE}

\section{A. Energetic Macroscopic Representation}

The FC-B-SC hybrid electric vehicle will be modelled in Energetic Macroscopic Representation (EMR). This is a graphical tool developed in 2000 [11], very helpful when studying complex systems and its energy management. The elements are connected considering the action-reaction principle and respecting physical causality. Physical causality is respected by considering only integral operations, discarding derivative operations. In physical systems the output is always delayed with respect to the input. In EMR each element is represented by a pictogram which internally includes the mathematical equations which describes the 
relationships between action and reaction inputs and outputs. Moreover, EMR does not only consider the representation of each element, but also complex control schemes and strategies. EMR has already proved to be useful in, e.g. vehicle [12] and fuel cell [13] applications, among others.

The vehicle simulated is a $32 \mathrm{~kW}$ fuel cell-batterysupercapacitor (Fig. 1). The power converter arrangement can be varied due to the multiple power energy systems, and have been studied in [5]. The complete system has three converters: one for the electric machine and two for the power sources. The number of power converters for the power sources can vary from none to three [5]. No converters imply a necessary oversizing of supercapacitors to allow its charge and discharge, as well as negative long term effects on fuel cell and battery due to excessive cycling. On the other hand, three converters allow a greater control [9], but it also increases weight, volume, costs and losses. An intermediate solution is the use of two converters for three power sources, leaving the third as a slack element. In this work we have chosen to interface fuel cell and supercapacitors with power converters, leaving the battery directly connected to the electric machine converter. This choice allows the voltage variation needed for the fuel cell and for, especially, the supercapacitors operation.

\section{B. Fuel Cell System}

Due to particularities in vehicle applications, such as fast start-up due to low temperature operation, PEM fuel cell (Proton Exchange Membrane) are commonly used in road transport applications.

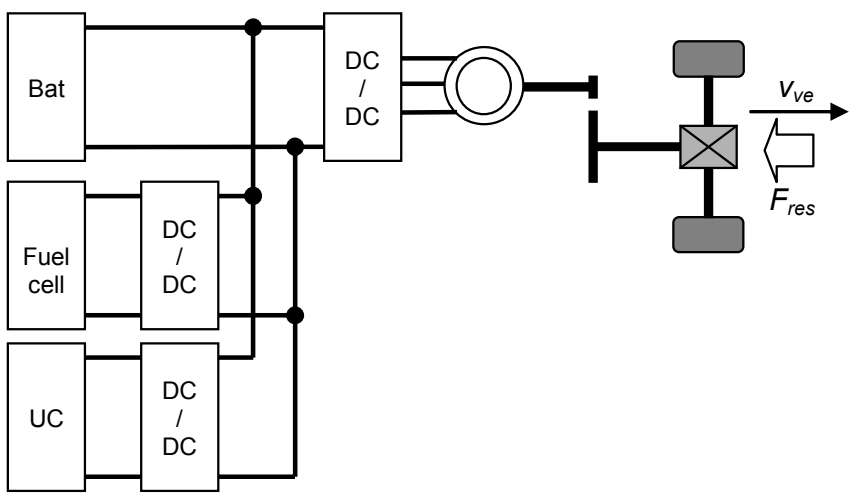

Fig. 1. Fuel cell-battery-supercapacitor hybrid electric vehicle

TABLE I

VEHICLE CHARACTERISTICS

\begin{tabular}{|c|c|}
\hline Vehicle mass & $1000 \mathrm{~kg}$ \\
\hline Vehicle frontal surface & $2 \mathrm{~m}^{2}$ \\
\hline Wheel diameter & $0.52 \mathrm{~m}$ \\
\hline Drag coefficient & 0.35 \\
\hline Air density & $1.223 \mathrm{~kg} / \mathrm{m}^{3}$ \\
\hline $\begin{array}{c}\text { Electric machine rated power } \\
\text { Electric machine armature } \\
\text { voltage }\end{array}$ & $32 \mathrm{~kW}$ \\
\hline
\end{tabular}

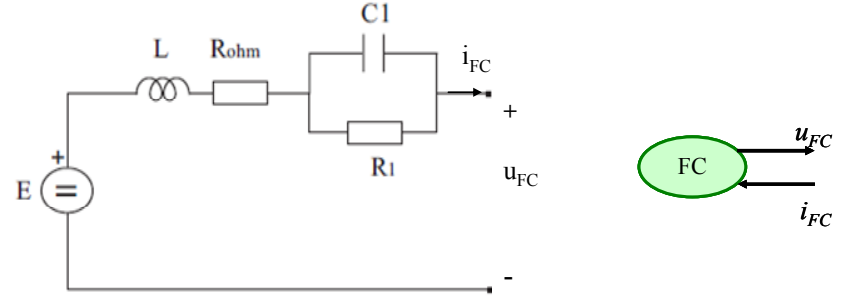

Fig. 2. Fuel cell EMR (left) and equivalent circuit (right)

Fuel cells include a stack, responsible for the power generation, and a number of ancillary systems, such as compressor, cooling system, humidification, etc. Therefore, it is a multiphysical and complex system. There is a wide range of modeling approaches to fuel cells. It can vary from stack centered models [14], to others which include auxiliary systems, such as [15]. or control oriented [16]. Equivalent models obtained by impedance spectroscopy enable easy interaction with other electric models. The topology of the circuit can present slight variations, depending on the author [17].

The PEM fuel cell model used in this work is an equivalent circuit (see Fig. 2) obtained by impedance spectroscopy and experimentally validated [18]. The tests were carried out on a Nexa Ballard fuel cell, which is a 1.2 $\mathrm{kW}, 22-50 \mathrm{~V}$ system with a maximum current of $50 \mathrm{~A}$. The model obtained has been scaled to represent a 300 cell stack with a voltage range of $138-318 \mathrm{~V}$.

The PEM fuel cell system EMR pictogram is a voltage source, represented by an oval block, as seen in Fig. 2. The output is the voltage computed by the fuel cell equations.

$$
U_{f c}(V)=E-R_{o h m} I_{f c}-\left(I_{f c}-C_{1} \frac{d}{d t} U_{C 1}\right) R_{1}
$$

The voltage $E$ depends on the stack temperature, the Faraday constant and hydrogen, oxygen and water partial pressures and the fuel cell standard voltage. The resistances and capacitor voltages represent the ohmic and double layer capacitance phenomena which take places in the stack.

The fuel cell is connected to the rest of the system via an inductance, to smooth the current ripple, and a dc-dc converter. Equations for both systems are presented.

$$
\begin{gathered}
u_{f_{c}}(t)-u_{\text {ind } f_{c}}(t)=L \frac{d}{d t} i_{f_{c}}(t)+R i_{f_{c}}(t) \\
\left\{\begin{array}{l}
i_{c h o p_{-} f c}(t)=m_{2}(t) i_{f_{c}}(t) \\
u_{\text {ind_f } f_{c}}(t)=m_{2}(t) u_{b a t}(t)
\end{array}\right\}
\end{gathered}
$$

\section{Batteries}

Battery modeling has been deeply studied due to the complex phenomena which take place, both in the short and long term. A widely accepted test procedure to model batteries is the electrochemical impedance spectroscopy [19], [20]. Ni-Mh, have already been successfully been used in Toyota Prius, and is the technology chosen for this work.

The battery model used is based on the model available in the Matlab/Simulink library. It is a $300 \mathrm{~V} 10 \mathrm{Ah} \mathrm{Ni-Mh}$ battery. The battery EMR pictogram is an oval element, with voltage as output and current as input, as depicted in Fig. 3. 

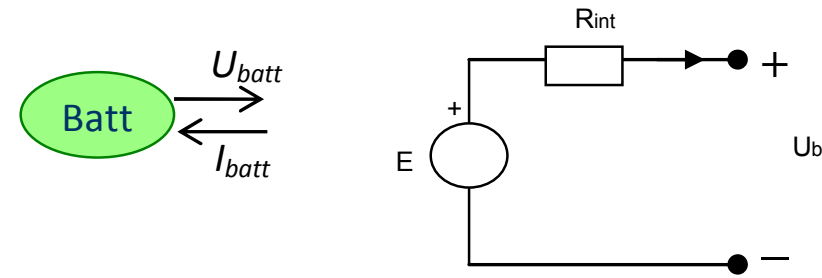

Fig. 3. Battery EMR (left) and equivalent circuit (right)

For the correct computation of the battery model, it is necessary to estimate the battery state-of-charge $(\mathrm{SoC})$. The estimation of the $S o C$ can be a complex task. Especially in nonflooded batteries, as the acid concentration of the electrolyte, which is normally a good indication of the battery $S o C$, cannot be directly measured. The different methods can be consulted in [21]. The method chosen for this work is the ampere hour count, taking into account the ampere hour efficiency.

$$
S o C_{t}(\%)=S o C_{t-1}(\%)-\frac{100 \eta}{C_{n}} \int i(t) d t
$$

\section{Supercapacitors}

Supercapacitors enable high power delivery or braking, which is an attractive characteristic for transport applications. Supercapacitor modeling can yield a variety of equivalent circuits. Different authors present equivalent circuits with different topology, as [22] and voltage equalization [23].

The supercapacitor model used in this work is based on an previous experimentally validated work [24] for a 3000 F 2.5 V Maxwell Boostcap element. The model has been scaled to a 120 series connected cell pack. The EMR pictogram for a supercapacitor is also a voltage source, represented again by an oval element (Fig. 4).

$$
\begin{gathered}
u_{u c}(t)=u_{L}(t)+\int \frac{1}{C_{1}} i_{u c}(t) d t+\int \frac{1}{C_{2}}\left(i_{u c}(t)-\frac{u_{C 2}(t)}{R_{2}}\right) d t \\
\ldots+\int \frac{1}{C_{3}}\left(i_{u c}-\frac{u_{C 3}(t)}{R_{3}}\right) d t
\end{gathered}
$$

Supercapacitors are connected to the dc bus through an inductance and a boost dc-dc converter.

$$
\begin{gathered}
u_{s c}(t)-u_{\text {ind_sc }}(t)=L \frac{d}{d t} i_{s c}(t)+R i_{s c}(t) \\
\left\{\begin{array}{l}
i_{c h o p_{-} s c}(t)=m_{3}(t) i_{s c}(t) \\
u_{\text {ind_sc }}(t)=m_{3}(t) u_{\text {bat }}(t)
\end{array}\right\}
\end{gathered}
$$

\section{E. Mechanical part and environment}

The mechanical part of a hybrid electric vehicle can present different topologies [12].
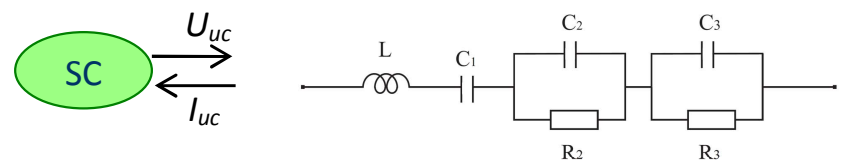

Fig. 4. Supercapacitor EMR (left) and equivalent circuit (right)

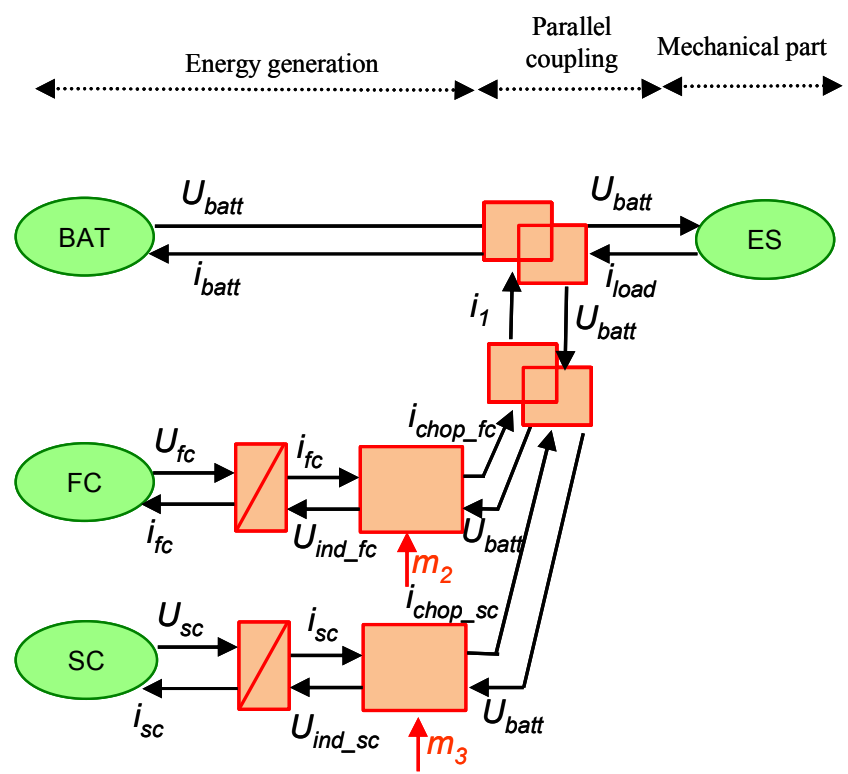

Fig. 5. EMR for the fuel cell-battery-supercapacitor vehicle

The machine used for this simulation is a permanentmagnet DC machine. This implies that no external excitation system needs to be controlled. The electric machine is not directly coupled to the wheels, but needs to be interfaced by a differential in order to reduce the shaft speed, increase the torque and distribute it to both driven wheels. The gear multiplies the torque to be transmitted to the differential by a factor of 5. The differential will transmit the torque to left and right wheels, allowing a different speed for each if necessary. All the mechanical part has been included in an electric source at the dc bus, as seen in Fig. 5.

\section{F. Parallel coupling}

At the dc bus the voltage will be imposed by the battery, whilst the currents will be distributed in a parallel node. To facilitate later control schemes, the parallel connection is separated in two.

$$
\left\{\begin{array}{l}
i_{\text {load }}(t)=i_{\text {bat }}(t)+i_{1}(t) \\
i_{1}(t)=i_{\text {chop_fc }}(t)+i_{\text {chop_sc }}(t)
\end{array}\right\}
$$

\section{INVERSION BASED CONTROL THROUGH EMR}

Once the complete system is represented in EMR, it is necessary to be able to control it. The ability to do so is one of the interesting characteristics of EMR.

The control is done by firstly defining the control loops in the system. For this purpose it is important to define which are the system tuning and objective variables. In this case there are two control loops. One is related to the mechanical part of the system and the other one to the power generation system.

The control loop for the mechanical part has the speed as the objective variable and the power converter of the electric machine as the tuning variable. This loop is included in the electric source which simulates the mechanical part. 


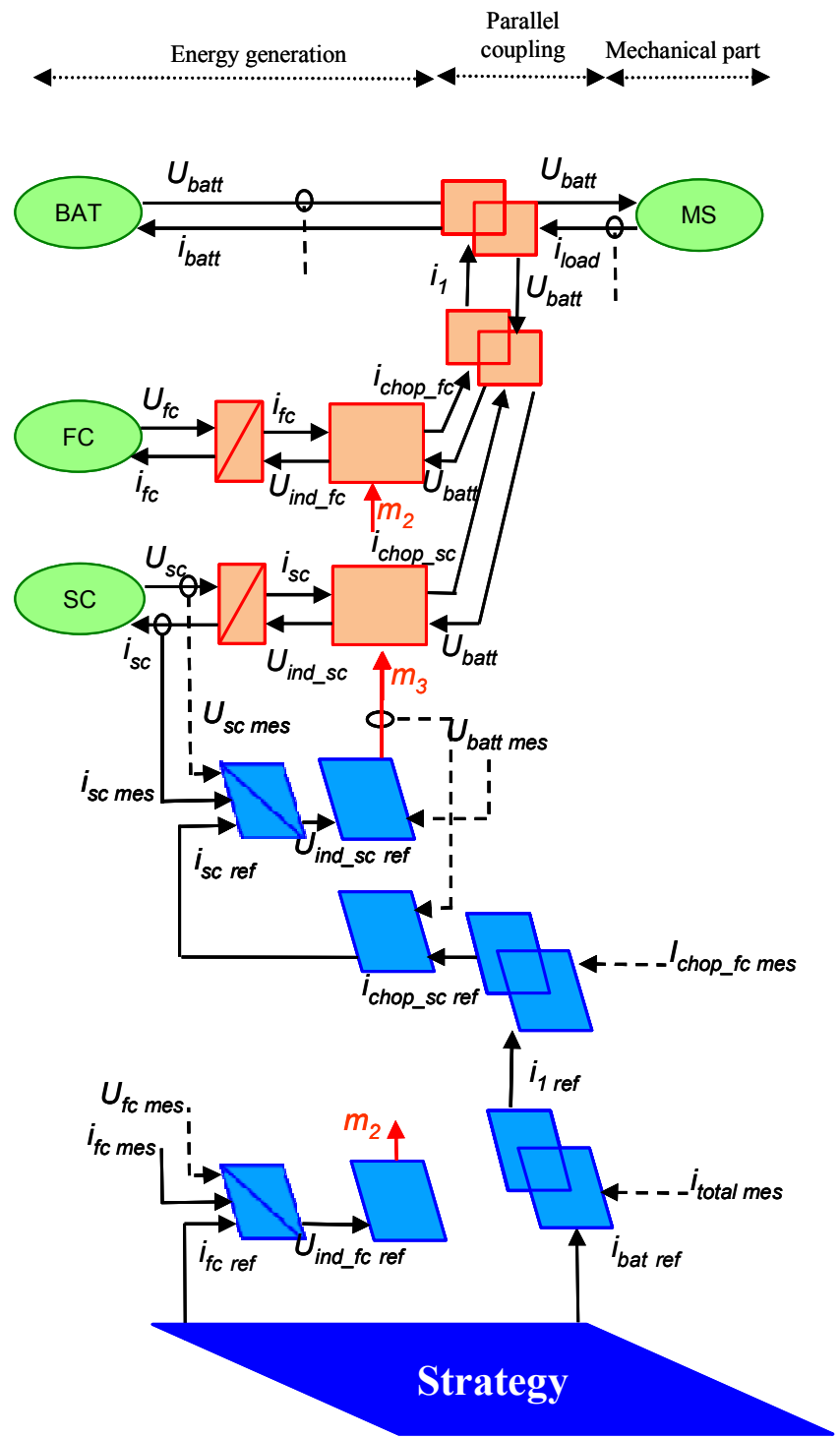

Fig. 6. EMR of the fuel cell-battery-supercapacitor system with inversion based control

The power generation control loop has as objective the control of the current distribution in the dc bus. The current distribution is related to the first Kirchhoff law (8), where the current on the dc bus $\left(i_{\text {total }}\right)$ is imposed by the dc machine. Therefore, only two currents need to be controlled to obtain the three currents. The choice of which of the two currents must be controlled will depend on the strategy, as seen in Fig. 6. This work will present the example of controlling the fuel cell current and battery current. Fuel cell current control equations:

$$
\left\{\begin{array}{l}
u_{\text {ind_f } f c_{-} r e f}(t)=u_{f c_{-} m e s}(t)-C_{P I}(t)\left[i_{f c_{-} r e f}(t)-i_{f c_{-} m e s}(t)\right] \\
m_{2_{-} r e f}(t)=\frac{u_{\text {ind_f } f c_{-} r e f}(t)}{u_{\text {bat_mes }}(t)}
\end{array}\right\}
$$

Battery current control loop related to the inversion based control equations are presented.

$$
\left\{\begin{array}{l}
i_{1_{-} r e f}(t)=i_{\text {load_mes }}(t)-i_{\text {bat_ref }}(t) \\
i_{c h o p_{-} s c_{-} r e f}(t)=i_{1_{-} r e f}(t)-i_{\text {chop_f } f c_{-} m e s}(t) \\
i_{s c_{-} r e f}(t)=\frac{i_{c h o p_{-} s c_{-} r e f}(t)}{m_{3_{-} r e f}(t)} \\
u_{\text {ind_uc_ref }}(t)=u_{s c_{-} m e s}(t)-C_{P I}(t)\left[i_{s c_{-} r e f}(t)-i_{s c_{-} m e s}(t)\right. \\
m_{3_{-} r e f}(t)=\frac{u_{\text {ind_sc_ref }}(t)}{u_{\text {bat_mes }_{-}}(t)}
\end{array}\right\}
$$

The advantage is that fuel cell and battery are the elements that suffer more severe aging processes, so it is important to avoid excessive cycling.

Known the tuning and objective variables, it is possible to define the control system using the inversion principle. This principle is based on the idea of inverting each block until the objective variable is obtained. This objective should follow the reference generated by the strategy.

\section{SimUlation RESUlts}

The simulation results present the hybridization of a fuel cell-battery-supercapacitor system under a NEDC cycle (New European Driving Cycle), as shown in Fig. 7. A first strategy based on frequency selection is presented.

To avoid oxygen starvation on fuel cell systems, it is usual to avoid subjecting the fuel cell system to power bursts. This can be achieved by assigning as reference load currents with a frequency lower than $100 \mathrm{~Hz}$. On the other hand, supercapacitors are specially designed to endure sudden power bursts, both during supply or regenerative braking. Therefore, high frequency loads, above $10 \mathrm{~Hz}$ will be supplied or absorbed by the supercapacitor. This implies that intermediate frequencies will be the reference for battery current. Results are presented in Fig. 8 and 9.

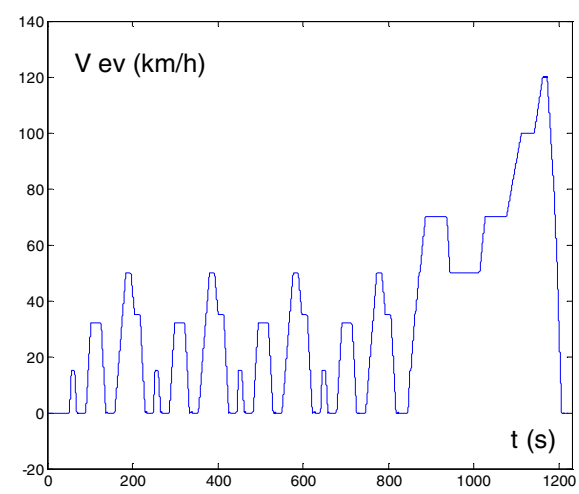

Fig. 7. NEDC driving cycle (upper) and load current (bottom) 

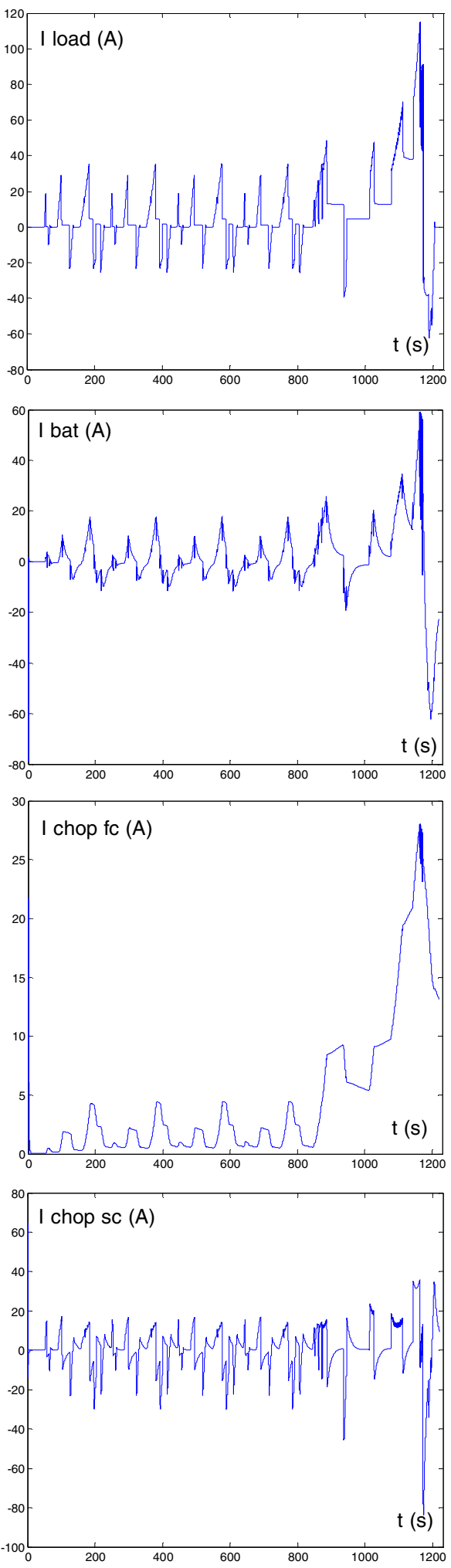

Fig. 8. Current distribution on the parallel coupling

The strategy must include limitations in each of the electrochemical energy sources. Limitations for maximum fuel cell current (50 A) are included. This limitation is due to the stack cross section. Any limitations for stack environment to guarantee correct operation is already carried out by the fuel cell system control. This control will make sure
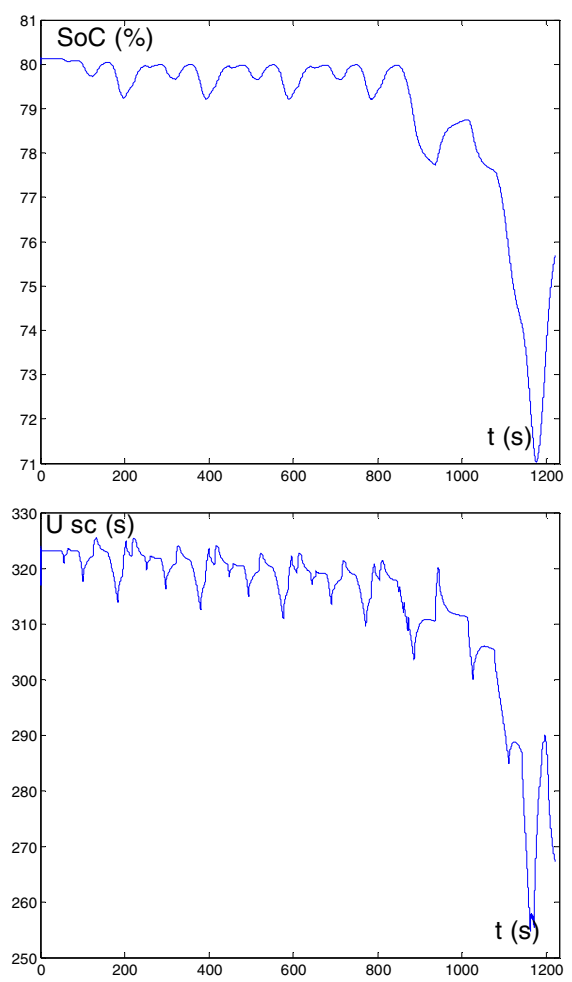

Fig. 9. Battery state-of-charge (upper) and supercapacitor voltage (bottom)

temperature, gas pressure and water content are the expected value for each operation point. The battery state-of-charge $(\mathrm{SoC})$, is limited to $60-80 \%$, to avoid deep discharges. Maximum voltage for supercapacitors must also be limited to $2.5 \mathrm{~V}$ per element. Supercapacitor voltage range is taken from 0 to $2.5 \mathrm{~V}$ per element, which is a wider range than the normally used 1.25-2.5 $\mathrm{V}$ range. This will allow a deeper discharge of the supercapacitors, which will enable a higher power recharge during regenerative braking.

\section{CONCLUSIONS}

In this paper we have obtained the energetic macroscopic representation of a fuel cell-battery-supercapacitor hybrid electric vehicle. The electrochemical energy systems models used were previously experimentally validated and adapted to the case power levels. An initial energy storage strategy was simulated, demonstrating EMR is a powerful tool for this issue. The next step will be to study how other energy management strategies affect each of the electrochemical energy systems involved.

\section{ACKNOWLEDGMENT}

Authors acknowledge financial support from the LEESS research group of the University Carlos III of Madrid (UC3M), from the scholarships for mobility of researchers of UC3M 2011 and the L2EP of the University of Lille. 


\section{REFERENCES}

[1] C. C. Chan, "The state-of-the-art of electric, hybrid, and fuel cell vehicles", Proceedings of the IEEE., vol. 95, no. 4, pp. 704-718, April 2007.

[2] M. Ceraolo, C. Miulli, and A. Pozio, "Modelling static and dynamic behaviour of PEM fuel cells on the basis of electrochemical description", Journal of Power Sources, vol. 113, pp. 131-144, January 2003.

[3] M.J. Kim, and H. Peng, "Power management and design optimization of fuel cell/battery hybrid vehicles", Journal of Power Sources, vol. 165, pp. 819-832, 2007.

[4] A. Bourke, "Ultracapacitors: why, how and where is the technology", Journal of Power Sources, vol. 91, pp. 37-50, November 2000.

[5] J. Bauman, and M. Kazerani, "A comparative study of fuel cell-battery, fuel cell-ultracapacitor and fuel cell-battery-ultracapacitor vehicles", IEEE Trans. Vehicular Techn, vol 57, no.2, pp. 760-769, March 2008.

[6] W. Gao, "Performance comparison of a fuel cell-battery hybrid powertrain and a fuel cell-ultracapacitor hybrid powertrain", IEEE Trans. On Veh. Techn., vol. 54, no. 3, pp. 846-855, May 2005.

[7] R. M. Dell, and D.A.J. Rand, "Energy storage technology for global energy sustainability", Journal of Power Sources, vol. 100, pp. 2-17, November 2001.

[8] J.M. Miller, "Energy storage system technology challenges facing strong hybrid, plug-in and battery electric vehicles", IEEE Vehicle Power Propulsion Conference, September 7-10 2009, Dearborne U.S.A.

[9] P. Thounthong, S. Raël, and B. Davat, "Energy management of fuel cell/battery/supercapacitor hybrid power source for vehicle applications", Journal of Power Sources, 2009.

[10] E. Shaltz, A. Khaligh, and P.O. Rasmussen, "Investigation of battery/ultracapacitor energy storage rating for a fuel cell hybrid electric vehicle", IEEE Vehicle Power and Propulsion Conference, September 35 2008, Harbin, China.

[11] A. Bouscayrol, B. Davat, B. de Fornel, B. François, J.P. Hautier, F. Meibody-Tabar and M. Pietrzak-David, "Multimachine multiconverter system: application for electromechanical drives", Eur. Phys. J, Appl. Phys., vol. 10, no. 2, pp. 131-147, May 2000.

[12] K. Chen, A. Bouscayrol, A. Berthon, P. Delarue, D. Hissel, and R. Trigui, "Global modeling of different vehicles", IEEE Vehicular Technology Magazine, vol. 4, no. 2, pp. 80-89, June 2009.

[13] L. Boulon, D. Hissel, A. Bouscayrol, and M.-C. Pera, "From modelling to control of a PEM fuel cell using energetic macroscopic representation", IEEE. Trans. Ind. Electron., vol 57, no.6, pp. 18821891, June 2010.

[14] P. Pathapati, X. Xue, and J. Tang, "A new dynamical model for predicting transient phenomena in a PEM fuel cell", Renewable Energy, vol. 30, pp. 1-22, 2005.

[15] L. Boulon, D. Hissel, A. Bouscayrol, and M.C. Péra, "From modelling to control of a PEM fuel cell using energetic macroscopic representation", IEEE Trans. Ind. Electron., vol. 57, no. 6, pp. 18821891, June 2010.

[16] C. Bordons, A. Arce, and A.J. del Real, "Constrained predictive control strategies for PEM fuel cells", Proceedings American Control Conference, Minneapolis, USA, June 14-16, 2006.

[17] X. Yuan, J. Sun, H. Wang, and J. Zhang, "AC impedance diagnosis of a 500 W PEM fuel cell stack. Part I: stack impedance”, Journal of Power Sources, vol. 161, pp. 920-928, 2006.

[18] L Gauchia, and J. Sanz, "A per-unit hardware-in-the-loop simulation of a fuel cell/battery hybrid energy system", IEEE Trans. Ind. Electron.. vol. 57, no.4, pp. 1186-1194, April 2010.

[19] E. Karden, S. Buller, and R.D. Doncker, "A method for measurement and interpretation of impedance spectra for industrial batteries", Journal of Power Sources, vol. 85, pp. 72-78, 2000.

[20] M. Thele, O. Bohlen, D. Sauer, and E. Karden, "Development of a voltage behavior model for NiMh batteries using an impedance based modeling concept", Journal of Power Sources, vol. 175, pp. 635-643, 2008.

[21] S. Piller, M. Perrin and A. Jossen, "Methods for state-of-charge determination and their applications", Journal of Power Sources, vol. 95, pp. 113-120, June 2001.

[22] S. Buller, E. Karden, D. Kok, and R.D. Doncker, "Modeling the dynamic behaviour of supercapacitors using impedance spectroscopy", 36th Industry Application Conference, vol. 4, pp. 2500-2504, Chicago, USA, September 2001.
[23] P. Barrade, 'Series Connection of Supercapacitors: Comparative Study of Solutions for the Active equalization of the Voltages, 7th International Conference on Modeling and Simulation of Electric Machines, Converters and Systems, 18-21 August, Ecole de Technologie Supérieure, Montreal, Canada.

[24] L. Gauchia, S. Castaño, and J. Sanz, "New approach to supercapacitor testing and dynamic modelling", IEEE Vehicle Power and Propulsion Conference, September 1-3 2010, Lille, France. 